\title{
Social Support and Psychological Distress among Adolescents in Foster Care
}

\author{
Sherifa Rabie Mohamed, Fadia Abd-El Hamed Mosallem, Naglaa Abd El Megied Mohamed, \& Amany Anter \\ Mohamed.
}

Psychiatric \& Mental Health Nursing, Faculty of Nursing - El Minia University.

Public Health \& Preventive Medicine, Faculty of Medicine- El-Minia University.

Psychiatric Nursing, Faculty of Nursing- Assiut University.

Psychiatric \& Mental Health Nursing, Faculty of Nursing, El-Minia University.

\begin{abstract}
:
There are 1.7 million orphans in Egypt, and the Egyptian foster care sector is largely a non-governmental relying on private support with minimal government supervision. The transition from living at home to living in foster care is difficult for anyone at this age. Psychological distress is one of the health problems faced by foster youth. Social agencies have no more power than the legal rights to offer support to these youths. Therefore, the aim of the study was to investigate the relationship between psychological distresses and social support provided to the adolescents in foster care. Subjects and methods: Three tools were utilized to measure the variables of the study: Sociodemographic data, Depression, Anxiety, Stress scale (DASS 42) and Norbeck Social Support Questionnaire (NSSQ). Results revealed that, $58 \%$ of subjects were males and more than half of the foster care adolescents came from rural area, poverty and divorce were the major reasons for entering foster care. Concerning level of psychological distress among the foster care adolescents, $77 \%$ of adolescents had mild to moderate stress, $60 \%$ had mild to moderate depression while more than half of them (54\%) suffered from severe to extreme anxiety. As regard social support; more than half of foster care adolescents $(52 \%)$ received support from their friends and males were more socially supported than females. Conclusion: Broken families (divorces) and poverty were the major reasons for placing children in foster care. Most of foster care adolescents had various levels of psychological distress especially depression and anxiety. Friends represented the main social support source for the foster care adolescents. Adolescents who had not anxiety had higher mean scores of social support than others. There is no a statistically significant differences between social support and psychological distress. Recommendations; Focusing on alternative families from relatives and neighbors, especially to orphans, those who came from broken families, or suffer from some circumstances of illness or economic hardship than foster care.
\end{abstract}

Key words: Adolescents• Foster care• Social support $\bullet$ Psychological Distress

\section{Introduction:}

In Egypt, a growing number of children are left abandoned usually in front of hospitals or near police stations. Social workers point to rising poverty and illegal marriages are the causes for the burgeoning multitudes of orphans left for the Ministry of Social Affairs to process and relocate to one of the scores of Egyptian orphanages. Almost none of these children will be adopted through legal means. In accordance with the tradition of the Prophet, Egyptian law explicitly states that no child can have his or her name changed in order to become part of another family. Thus, adoption, in the literal sense of the word, does not exist in Egypt. This is not to say that Islam does not allow its practitioners to take in and care for orphans. To the contrary, Islam encourages supporting orphans as a most blessed and generous endeavor. According to the hadith reported by $\mathrm{Al}$ Bukhari, the Prophet said, "me and the guardian of an orphan will be in Paradise like these two fingers and he joined his two fingers" (Fontes \& Wanchic, 2004).
The same author added that, Egyptian government uses the edicts of kafala, which mandates how individuals or corporations are allowed to provide for an orphaned child, as the basis for its laws on adoption. Basically, kafala dictates two mandates for helping orphans. The more commonly practiced mechanism is through donations to the institutions charged with caring for orphans, and the other is a form of foster care.

Foster care is a planned service that provides substitute family care with relatives or non relatives, for a child or young person. The service is provided when a child or young person's own family is unable to care for him/her for a temporary or extended period, until they reach the age at which they become independent (generally age 18 years) (Child Welfare League of America, 2004). Children entered foster care mainly because of maltreatment, abuse and neglect, parental substance abuse, and desertion by their families (Scott, 2008). 
Adolescents are young people between the ages of 10 and 19 years (WHO, 2012). Adolescent who entering the foster care system are at significant risk for behavioral and psychological problems. Adolescents in foster care share a back-ground of chronic poverty with associated familial disruptions, stresses, and social problems that predispose adolesc ents to emotional and cognitive problems. Experiences of maltreatment and neglect have also been linked with emotional problems (Lesli et al., 2000).

Fairbrother (2004) defined social support as the physical and emotional comfort given to us by our family, friends, co-workers and others. It is known that we are part of a community of people who love and care for us, and value and think well of us.

Social support plays an important role during the transition to adulthood. For young people, the transition to adulthood is a gradual process. Many continue to receive financial and emotional support from their parents or other family members until aged 18 years. This is in stark contrast to the situation confronting youth in foster care (Courtney et al., 2010).

Nugent and Masuku, (2007) mentioned that when children lose a parent or are separated from their community; their river of support dries up. They will not thrive unless the new community they are part of it can help them to be emotionally healthy.

When youth lack supportive, nurturing relationships, it can be difficult for them to find a constructive path in life. This can lead to a number of detrimental outcomes such as low levels of educational achievement, delinquent behavior, and mental health problems, which detract from their ability to be fully contributing members of society. Youth in foster care have more behavioral and emotional disorders, are more likely to experience suspensions, expulsions from school, and are also more likely to receive mental health services than youth generally. This suggests that the population of youth in foster care require a different kind of attention in terms of feasible and effective service interventions (Johnson, 2009).

The act of taking adolescents out of their homes, away from their parents and families and placing them in new and foreign environments put a high degree of psychological distress on them. This distress becomes compound in situations where adolescent are never reunified with their family (Hurley, 2011).

\section{Significance of the Study}

Youth in foster care are a 2-5 times higher rate of referral for clinical mental health services (Lois, 2007), they face more significant challenges and poorer outcomes than other youth at risk who are not in foster care (Johnson, 2010). Entering the foster care system itself presents a significant psychological stress; adolescents must cope with the effects of traumatic events precipitating their entry into foster care, face a temporary or permanent loss of their parents, and adjust to new families and living situations. In addition, foster care experiences may exacerbate psychological problems such as; depression and anxiety (Slymen \& Garland, 2000). Gilborn et al., (2006) added that exposure to trauma and daily stresses were strongly associated with depression and anxiety symptoms. On the other hand, social support was unavailable for these adolescents. In addition, there are no studies have been conducted about foster care children and adolescents at El-Minia governorate.

\section{subject and Methods}

The aim of the study was to assess social support and psychological distress among adolescents in fosters at El-Minia governorate.

Research design: A descriptive cross-sectional design was used in the study; such design fits the nature of the problem under investigation.

Setting of the study: This study was conducted in foster care centers at El-Minia governorate which includes ten foster cares distributed in four cities. They were divided into governmental institutions and non governmental organizations.

Study sample: Convenient sample of all adolescents from 11-19 years in El-Minia foster cares were 123 adolescents. The number of adolescents who agreed to participate in the study were 100 adolescents only (response rate was $81.3 \%$ ), in the period from first of January to end of July 2012. 
Box (1): Distribution of adolescents in El-Minia foster care:

\begin{tabular}{|c|c|c|c|c|}
\hline $\begin{array}{l}\text { Foster } \\
\text { care }\end{array}$ & $\begin{array}{c}\text { Center/ } \\
\text { City }\end{array}$ & Sex & Religion & $\mathrm{N} / \%$ \\
\hline $\begin{array}{l}\text { Institution } \\
\text { of Tarbiet } \\
\text { Al Banat }\end{array}$ & \multirow{4}{*}{ 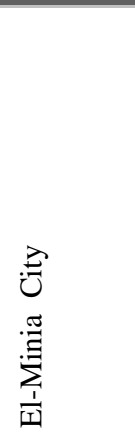 } & Females & Muslim & 11 \\
\hline $\begin{array}{l}\text { Institution } \\
\text { of Tarbiet } \\
\text { Al Banen }\end{array}$ & & Males & Muslim & 10 \\
\hline $\begin{array}{l}\text { Association } \\
\text { of Genoud } \\
\text { al Masieh }\end{array}$ & & Males & Christian & 10 \\
\hline $\begin{array}{l}\text { Association } \\
\text { of Al Banat } \\
\text { Al Kebteia }\end{array}$ & & Females & Christian & 10 \\
\hline $\begin{array}{l}\text { Association } \\
\text { of Al nahda } \\
\text { al rohiea }\end{array}$ & $\begin{array}{l}\text { Samalout } \\
\text { City }\end{array}$ & Males & Christian & 11 \\
\hline $\begin{array}{l}\text { Association } \\
\text { of Al-Ber\& } \\
\text { Al_Ehsan }\end{array}$ & \multirow[b]{4}{*}{ 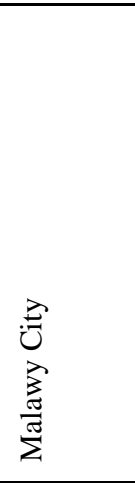 } & Males & Muslim & 11 \\
\hline $\begin{array}{l}\text { Association } \\
\text { of } \\
\text { Al-Rahma }\end{array}$ & & Females & Muslim & 8 \\
\hline $\begin{array}{l}\text { Association } \\
\text { ofAl-Salam } \\
\text { Al kebtiea }\end{array}$ & & Males & Christian & 3 \\
\hline $\begin{array}{l}\text { Association } \\
\text { of } \\
\text { Marri } \\
\text { Mourkes } \\
\end{array}$ & & Females & Christian & 13 \\
\hline $\begin{array}{l}\text { Association } \\
\text { of } \\
\text { AlNashat } \\
\text { Al Rohie }\end{array}$ & $\begin{array}{l}\text { Abo- } \\
\text { Korkas } \\
\text { City }\end{array}$ & Males & Christian & 13 \\
\hline \multicolumn{4}{|l|}{ Total } & 100 \\
\hline
\end{tabular}

\section{Tools of data collection:}

\section{1- Personal data questionnaire:}

An interview questionnaire was developed by the researcher and covered the following items: Personal data, e.g., living in foster care and relationship with foster family.

2-Norbeck Social Support Questionnaire (NSSQ): The NSSQ was developed by Norbeck (1995) and designed to measure perceived support available to the individuals. Respondents were asked to list significant persons (by first name or initials only) in their life. They were to consider all the people who provide personal support for them or who were important to them at the time of the survey. The respondents then specified the category of relationship for each person from a list of categories presented in the instructions.

The NSSQ consists of 9 questions which are designed to measure each of the functional properties of social support (affect: question 1+2; affirmation, question $3+4$; and aid: question $5+6$ ), the network properties of social support (size, duration of relationships and frequency of contact) (question 7+8), and recent losses of important relationships (question 9). The respondents were asked to rate each of their members to these questions on a 5-point Likert Scale rated. (0) not at all, (1) a little, (2) moderately, (3) quite a bit and (4) a great deal. Reliability falls between $83.1 \%$ and $100 \%$ for the test-retest. The NSSQ is commonly known to be a comprehensive tool for measuring the disposition and style of social support and it has established as a reliable and valid measure of social support (Connelly, 1998)

Box (2): Scores for Normative Data Published by Norbeck, (1995):

\begin{tabular}{|l|c|c|}
\hline \multicolumn{1}{|c|}{ NSSQ } & Mean & S.D. \\
\hline Affect & 73.49 & 36.25 \\
\hline Affirmation & 66.06 & 32.3 \\
\hline Aid & 62.35 & 32.24 \\
\hline Total functional & 201.90 & 95.87 \\
\hline
\end{tabular}

\section{3- Depression, Anxiety and}

Stress Scale 42 (DASS42):

The DASS is a 42-items questionnaire which includes three self-report scales designed to measure the negative emotional states of depression, anxiety and stress. Each of the three scales contains 14 items. The Depression scale assesses dysphoria, hopelessness, devaluation of life, self-depreciation, lack of interest/involvement, anhedonia, and inertia. The Anxiety scale assesses autonomic arousal, skeletal muscle effects, situational anxiety, and subjective experience of anxious affect. The Stress scale is sensitive to levels of chronic non-specific arousal. It assesses difficulty relaxing, nervous arousal, and being easily upset/agitated, irritable/over-reactive and impatient. Respondents are asked to use 4-point severity/frequency scales to rate the extent to which they have experienced each state over the past week ranges from: (0) didn't apply to me at all, (1) applied to me to some degree or some of the time; (2) applied to me at considerable degree or good part of time to (3) apply to me very much or most of the time, in order to rate the extent to which they have been experienced. The total score for this scale ranges from 42-126. The higher score indicates negative emotional status. Validity coefficients were found to be high $(0.87$ and 0.84 respectively). Reliability of the three subscales are considered adequate and test-retest is likewise considered adequate with 0.71 for depression, 0.79 
for anxiety and 0.81 for stress (brown et al., 1997), while the researcher found that 0.93 for depression, 0.92 for anxiety and 0.94 for stress.

Box (3) scoring system for DASS scale is:

\begin{tabular}{|l|c|c|c|}
\hline & Depression & Anxiety & Stress \\
\hline Normal & $\mathbf{0 - 9}$ & $\mathbf{0 - 7}$ & $\mathbf{0 - 1 4}$ \\
\hline Mild & $\mathbf{1 0 - 1 3}$ & $\mathbf{8 - 9}$ & $\mathbf{1 5 - 1 8}$ \\
\hline Moderate & $\mathbf{1 4 - 2 0}$ & $\mathbf{1 0 - 1 4}$ & $\mathbf{1 9 - 2 5}$ \\
\hline Severe & $\mathbf{2 1 - 2 7}$ & $\mathbf{1 5 - 1 9}$ & $\mathbf{2 6 - 3 3}$ \\
\hline Extremely & $\mathbf{2 8 +}$ & $\mathbf{2 0 +}$ & $\mathbf{3 4 +}$ \\
\hline
\end{tabular}

Procedure:

1- Preparatory phase:

An official letter was sent from the dean of the Faculty of Nursing, Minia University, to the Undersecretary of the Ministry of Social Solidarity asking for permission to collect data. The aim and process of study were briefly explained through direct personal communication with the adolescents in foster care.

\section{2- Pilot Study:}

A pilot study was conducted at the beginning of the study. It included $10 \%$ of the total sample to investigate the feasibility of data collection tools and their clarity. This sample was included in the study later.

\section{3- Data collection:}

Data were collected by the researcher in the period from January to July 2012 (in 7 months). The researcher went to each foster care in each city in the governorate two days per week (Saturday and Thursday from 9 am to $2 \mathrm{pm}$ ). The researcher had interview with all foster youths and collect data from them; this interview took about 25 minutes with every youth. Data were collected from 6-7 youths every day.

\section{4- Ethical consideration:}

The following ethical considerations were respected from the beginning of collection of data:

- Oral consents were obtained from undersecretary of the Ministry of Social Solidarity.

- Oral and written informed consents were obtained from the adolescents.

- The researcher ensured that confidentiality was maintained during and after the research process.

- The participant's dignity and privacy were maintained and respected throughout the research process.

\section{Statistical Analysis:}

The content of each scale was analyzed, categorized and then coded by investigator. Subjects' responses to each category were tabulated separately by using statistical package for social science (SPSS) version 13. Descriptive statistics were calculated as frequencies, percentage, mean and standard deviation. T-test was also used. Probability (P-value) is considered significant at/or less than 0.05 and considered highly significant at or less than 0.001 . 
Results:

Table (1) Frequency distribution of the Socio-demographic characteristics of foster care adolescents (n=100)

\begin{tabular}{|c|c|c|}
\hline Characteristics & NO. & $\%$ \\
\hline $\begin{array}{l}\text { 1. Sex } \\
\text { D Male }\end{array}$ & 58 & 58 \\
\hline - Female & 42 & 42 \\
\hline $\begin{array}{l}\text { 2. Age } \\
\text { D } 11-13 \text { years }\end{array}$ & 40 & 40 \\
\hline D 14-17 years & 50 & 50 \\
\hline D >17 years & 10 & 10 \\
\hline Mean $\pm \mathrm{SD}=14.3 \pm 2.14$ & & \\
\hline $\begin{array}{l}\text { 3.Reasons for entry foster care } \\
\text { d Orphan }\end{array}$ & 17 & 17 \\
\hline D Poverty & 21 & 21 \\
\hline - Divorce & 40 & 40 \\
\hline - Son's or daughter of prisoner & 3 & 3 \\
\hline a Foundling & 19 & 19 \\
\hline $\begin{array}{l}\text { 4. Place of home before entering foster care } \\
\text { a No home (foundling adolescents) }\end{array}$ & 18 & 18 \\
\hline D Urban & 17 & 17 \\
\hline a Rural & 65 & 65 \\
\hline $\begin{array}{l}\text { 5. Educational level } \\
\text { - Illiterate }\end{array}$ & 5 & 5 \\
\hline - Primary & 20 & 20 \\
\hline a Preparatory & 50 & 50 \\
\hline - Secondary & 25 & 25 \\
\hline
\end{tabular}

Table (2): Frequency distribution of the foster care adolescents according to some variables related to Living in foster care $(n=100)$ :

\begin{tabular}{|c|c|c|}
\hline ITEMS & NO & $\%$ \\
\hline $\begin{array}{l}\text { 1. Stay in foster care } \\
\text { a Short term (temporary until relieve cause) }\end{array}$ & 2 & 2 \\
\hline - Long term (Permanent until age of exit, 18 years) & 98 & 98 \\
\hline $\begin{array}{l}\text { 2. Duration of stay in foster care } \\
\text { a } 6 \text { months to } 1 \text { year }\end{array}$ & 6 & 6 \\
\hline D More than 1 year to 3 years & 26 & 26 \\
\hline - More than 3 years & 68 & 68 \\
\hline $\begin{array}{l}\text { 3. Frequency of relative's visits } \\
\text { a No visits }\end{array}$ & 19 & 19 \\
\hline D Weekly & 22 & 22 \\
\hline - Monthly & 35 & 35 \\
\hline D Once in year & 24 & 24 \\
\hline $\begin{array}{l}\text { 4. Relationship with foster family } \\
\text { a No relation }\end{array}$ & 27 & 27 \\
\hline - Good relation & 68 & 68 \\
\hline D Excellent relation & 5 & 5 \\
\hline $\begin{array}{l}\text { 5. What do you do when exposed to a problem? } \\
\text { a Tell my foster family }\end{array}$ & 16 & 16 \\
\hline - Tell my friends & 30 & 30 \\
\hline a Solve problem by my self & 54 & 54 \\
\hline
\end{tabular}


Table 3: Frequency distribution of the studied subjects according to social support (Norbeck Social Support Questionnaire (NSSQ) $n=(100)$ Personal Network members $(n=500)$

\begin{tabular}{|l|l|l|}
\hline Relation of network members; & $\mathbf{N}$ & $\mathbf{\%}$ \\
\hline Spouse/ partner & 0 & 0 \\
\hline Family/ Relatives & 108 & 21.6 \\
\hline Friends & 260 & 52 \\
\hline Work/School associates & 0 & 0 \\
\hline Neighbors & 0 & 0 \\
\hline Counselor or therapist & 26 & 5.2 \\
\hline Health care providers & 0 & 0 \\
\hline Minister, priest or rabbi & 20 & 4 \\
\hline Others e.g. supervisors & 86 & 17.2 \\
\hline Total & 500 & $100 \%$ \\
\hline Total & 500 & $100 \%$ \\
\hline
\end{tabular}

Table (4): Comparison between social support of the foster care adolescents and normative subscales of social support $(\mathbf{N S S Q}) \mathbf{n}=(\mathbf{1 0 0})$

\begin{tabular}{|l|l|l|l|}
\hline \multicolumn{1}{|c|}{ NSSQ } & \multicolumn{1}{|c|}{$\begin{array}{c}\text { Studied Scores } \\
\text { Mean } \pm \text { SD }\end{array}$} & \multicolumn{1}{c|}{$\begin{array}{c}\text { Normative Scores } \\
\text { Mean } \pm \text { SD }\end{array}$} & \multicolumn{1}{c|}{ - value } \\
\hline Affect & $28.65 \pm 5.26$ & $73.49 \pm 35.25$ & $0.001 * *$ \\
\hline Affirmation & $21.73 \pm 6.47$ & $66.06 \pm 32.33$ & $0.001 * *$ \\
\hline Aid & $20.08 \pm 6.64$ & $62.35 \pm 32.24$ & $0.001 * *$ \\
\hline Total functional & $74.39 \pm 13.68$ & $201.90 \pm 95.87$ & $0.0001 * * *$ \\
\hline $\mathbf{P}<\mathbf{0 . 0 5} \quad * * \mathbf{P}<\mathbf{0 . 0 0 1} \quad * * \mathbf{P}<\mathbf{0 . 0 0 0 1}$ &
\end{tabular}

Table (5): Frequency distribution of psychological distress levels among the foster care adolescents (n=100):

\begin{tabular}{|l|l|l|l|}
\hline \multicolumn{1}{|c|}{ Psychological distress } & \multicolumn{1}{c|}{ Normal } & \multicolumn{1}{c|}{ MildlModerate } & \multicolumn{1}{c|}{ SeverelExtreme } \\
\hline Stress & $17 \%$ & $77 \%$ & $6 \%$ \\
\hline Anxiety & $10 \%$ & $36 \%$ & $54 \%$ \\
\hline Depression & $8 \%$ & $60 \%$ & $32 \%$ \\
\hline
\end{tabular}

Table (6): Relation between psychological distress and social support among foster care adolescents (N=100):

\begin{tabular}{|l|c|c|c|c|}
\hline \multirow{2}{*}{ Psychological Distress } & Sample & $\mathbf{N}$ & $\begin{array}{c}\text { Total functional social support } \\
\text { Mean } \pm \text { sd }\end{array}$ & \multirow{2}{*}{ P } \\
\hline \hline \multirow{3}{*}{ Stress } & Normal & 17 & $73.70 \pm 17.73$ & \multirow{2}{*}{0.39} \\
\cline { 2 - 4 } & Mild/ Moderate & 77 & $69.41 \pm 13.64$ & \\
\cline { 2 - 4 } & Severe/ Extreme & 6 & $74.66 \pm 6.40$ & \multirow{2}{*}{0.50} \\
\cline { 2 - 4 } Anxiety & Normal & 10 & $75.20 \pm 12.62$ & \\
\cline { 2 - 4 } & Mild/ Moderate & 36 & $70.48 \pm 14.61$ & \\
\cline { 2 - 4 } & Severe/ Extreme & 54 & $69.58 \pm 13.77$ & \\
\hline \multirow{3}{*}{ Depression } & Normal & 8 & $66.00 \pm 13.04$ & \\
\cline { 2 - 4 } & Mild/ Moderate & 60 & $70.03 \pm 13.87$ & \\
\cline { 2 - 4 } & Severe/ Extreme & $32.37 \pm 14.34$ & \\
\hline
\end{tabular}


Table (1) : demonstrates the distribution of the foster care adolescents according to socio-demographic characteristics. It shows that adolescent males represented $58 \%$. Half of the studied subjects were in the age group 14-17 years and half of them (50\%) were in preparatory school. Divorce represented the most common reason for entering foster care (40\%) followed by poverty $(21 \%)$. Most of foster care adolescents $(65 \%)$ came from rural areas.

Table (2) : reveals the distribution of the foster care adolescents according to the presence of some variables include stay in foster care, duration of stay in foster care, frequency of relative's visits and relationship with foster's families. The majority of adolescents in foster care $(98 \%)$ were placed until the time of exit at age of 18 years (long term foster care). Regarding to duration of stay in the foster care, $68 \%$ of adolescents were living more than 3 years in it, $35 \%$ of them were visited by their relatives monthly, $68 \%$ had a good relationship with their foster families, while $54 \%$ solved their problems with themselves.

Table (3) : the first area of social support perceptions held by the adolescents examined represented the entire selection of relation of social support members (total network members listed $=500$ ) 5 members were listed by each respondents (100 adolescents) in the study. This table illustrates that the most frequently listed categories were friends (52\%) followed by family or relatives $(21.6 \%)$ then supervisors were $17.2 \%$ and only $4 \%$ for minister, priest or rabbi.

Table (4) : illustrates the difference in social support of foster care adolescents and normative scores. Foster care adolescents had significantly lower mean scores of social support than normative scores.

Table (5) : shows the distributions of psychological distress levels among the foster care adolescents. More than three quarters $(77 \%)$ of the studied subjects were suffering from mild to moderate levels of stress and more than half (54\%)of them suffering from severe to extreme levels of anxiety. While mild to moderate levels of depression symptoms appeared in nearly two thirds $(60 \%)$ of foster care adolescents.

Table (6) : illustrates the relation between psychological distress and social support. Among the studied subjects, the foster adolescents who had normal levels of anxiety had higher mean scores of social support than others. There is no a statistically significant differences between social support regarding different levels of psychological distress.

\section{Discussion:}

The present study demonstrated that the government supported only two foster cares at El-Minia city which are institution of Tarbiet El -Banien \& ElBanat, this support was in the form of budget and foster family were employee in the government, but other foster care at El-Minia governorate were organizations based on donations. Only 4 foster cares were for females and the rest were male foster care centers. This could be attributed to certain beliefs in Upper Egypt that housing girls in the foster care represents a stigma for their families unlike boys, evidenced by in Samalout and Abo Korkas cities where there were foster cares for males only.

Concerning to religion of foster care centers, more than half of them were Christians where they were non governmental organizations, and only $40 \%$ were Muslims among them 2 government institutions and 2 non governmental organizations. This could be attributed to the fact that Egyptian religion is Islam and in Egypt, Kafala system is applied in all centers at El-Minia city which supports orphans and poor people in their homes.

These results are in greatly consistent with the results of Ethnasios, (2012) who reported that, Egyptian orphanage sector is largely a non-governmental enterprise that is privately controlled. Because this sector is community-based, no two orphanages are alike; one orphanage can have many donors and be well-financed while another may not have leaders with an acumen for fund-raising and be poorly financed; one orphanage can be for Muslim boys and another can be for Coptic girls; one orphanage may specialize in housing disabled orphans while another may only take in street children.

The study results showed that more than half of the foster care adolescents were from rural areas. This could be attributed to the lower socio-economic status of rural areas. It was found that half of adolescents were falling in the age group ranging between 14-17years old and they were in the preparatory school. These results are partially consistent with those of Stukes \& Bent, (2009) who found that the adolescents were falling in age group ranging between 11-17years old were $46 \%$ in the United State foster care. As regards the reasons of entering foster care at ElMinia governorate, divorce (broken families) and poverty (low economic income) represented the major reasons with $(40 \% \& 21 \%$ respectively). This could be related to absence of the care giver and it may be related to low socio-economic status of others relatives. Oosterman et al., (2007) mentioned that, family disintegration, which is the characteristic of modern societies, where statistics indicate increasing the rates of divorce in recent years, causing a negative impact on family care for their children, coupled with weak family ties between members of the extended family, which made the search for child 
care in the foster care the alternative choice in many cases.

This is nearly consistent with the result of Debra $\boldsymbol{\&}$ Kelly (2003) who divided reasons of entry foster care into parent reasons (such as abuse, neglect, abandonment, etc.), child reasons (such as disabilities, mentally retarded, visually hearing impaired....etc.) and other reasons (such as parents jailed, removed by court); they found that parents reasons represented $70.5 \%$ followed by child reasons $25 \%$ then other reasons $4.5 \%$.

In the same aspect, Adly (2012) reported that, socioeconomic studies showed that, financial constraints and the extreme poverty levels that people face are major contributors to the rising foster care rates in Egypt.

As regards the type of foster care placement, nearly all cases $(98 \%)$ were placed for the time of exits (18 years for males and until marriage of females). Only $2 \%$ of them, who were sons of prisoners, were placed temporary in foster care. This could be attributed to the fact that their reasons of entering foster care did not improve and those adolescents could not return to their biological families. This result is partially consistent with the result of Yvonne et al., (2008) who found that, $(48 \%)$ placed in foster care have no relation with foster family, $7 \%$ return home with their birth parents and the rest placed in homes of a relative. Also this result is nearly consistent with the result of Chipungu and Goodley, (2004) who found that as regards placement type, most of children are placed in non-relative foster homes, but substantial numbers are also placed with relatives or in group homes or institutions.

Concerning to the duration that adolescents spent in the foster care, more than half of the respondents spent more than three years, and more than one third of them were visited by their relatives monthly. These findings were nearly consistent with the findings of Whelan, (2003) who found that, the overall length of time youth were separated from their families, just under one-half (46\%) reported being separated for more than five years. About onethird were visited by their biological families at least weekly, and almost two-thirds were visited at least monthly.

The current results revealed that the relationship between adolescents and foster family were good in more than half of foster care adolescents and 54\% solved their problems with them selves. This could be related to the mutual respect between adolescents and foster families, but this relationship did not reach to the extent considered trusted to tell them their problems and the presence of an environment that did not maintain adolescents' privacy and feeling of security. These findings were nearly consistent with the findings of Wertheimer, (2002) who found that, almost all of the youth (97\%) had a close positive relationship with at least one adult in foster care. When they were asked who are the people would contact if foster youth need help, $73 \%$ of adolescents reported friends.

Harter (2006) reported that, adolescence is a time of significant social, cognitive, physical, and emotional change; youths begin to move away from their families as their primary social group and move toward the peer group. They also begin to exercise independence in their decision making and develop a more concrete identity regarding who and what they want to be and do.

Taylor, (2011) stated that aid (tangible) support is the provision of financial assistance, material goods, or services. Also, called instrumental support, this form of social support encompasses the concrete, direct ways people assist others. Affect and affirmation (emotional) support is the offering of empathy, concern, affection, love, trust, acceptance, intimacy, encouragement, or caring. It is the warmth and nurturance provided by sources of social support. Providing emotional support can let the individual know that he or she is valued.

The current study revealed that, the foster care adolescents received emotional support more than aid (tangible) support. This could be attributed to; the foster care youth receive tangible support from donors, ministry or administration of association in the forms of clothes, foods, games or school kits and these gifts provided to them in festivals. But when any adolescent had a crisis, helshe found support from his her friend who had only emotional support. So they felt emotional support from their friends than other support. These findings are greatly consistent with the normative data of Norbeck et al., (1983) social support scale, although these findings were lower than normative results of scale.

As regard psychological distress, in the present study, the results demonstrated that, more than two-thirds of studied subjects were suffering from mild to moderate levels of stress. This could be attributed to many factors such as, developmentally, this stage of life has been characterized as stressful and filled with uncertainty (Arnett, 2000), by nature of entering foster care, these youth have experienced stressful life events, such as removal from home, stress related to being in the system, and in many cases prolonged abuse and/or neglect (Britner \& Kramer, 2005, Courtney et al., 2001 and Collins, 2001).

This study proved that there is no significant relation between social support and psychological distress (stress, anxiety and depression). This could be attributed to the very low social support level, in comparison to the normative social support scale. 
This low social support could be attributed to infrequent family visits and lack of trust in the surroundings so most of adolescents depended on themselves in solving problems and most of supporters were friends who were in the same age and enabled to give positive support.

These findings are not in consistent with the findings of Dzulkifli, (2010) who found that the relationship between social support and psychological problems indicate that there are significant negative correlations between social support and depression, social support and anxiety, and social support and stress.

Other studies done by Calvete $\boldsymbol{\&}$ Smith (2006) found that support from family and friends have been found to reduce the impact of psychological problems. Without enough support from family and friends, they would be vulnerable to depression, stress and anxiety. However, Dollete (2004) stated that social support could act as a protective factor that could decrease psychological problems such as stress.

\section{Conclusions:}

Based on the results of the present study it could be concluded that, broken families (divorces) and poverty were the major reasons for placing children in foster care. This could be explained by the fact of the low economic living of the city. Most of foster care adolescents had various levels of psychological distress especially depression and anxiety. Friends represented the main social support source for the foster care adolescents; this could be attributed to the total separation of these children from their relatives. Males were socially supported than females. Also the results showed that; type of placement in foster care had significant influence on the psychological distress. Social support for these adolescents was extremely lower than normative figures so, it had no significant relation with psychological distress.

\section{Recommendations based on results:}

- Due to negative effects of foster care on adolescents and on society in general, must make every effort to reduce dependence on care through foster care, and make it only the last choice and focus instead on care through alternative families of relatives and neighbors, especially to orphans, those who come from broken families, or suffer some circumstances of illness or economic hardship.

- The relatives should be encouraged to assume their responsibilities to their relatives, can also call neighbors to be foster parents of the child, especially as some of the neighbors with the length of years neighborhood become a people of the child.
- Create of an office in the Ministry of Social Solidarity could be called "alternative family support office," its mission is to provide social, psychological support and counseling for alternative families to assist them in solving the problems they face, and increase the efficiency of care of persons deprived from family care.

- Use different media in appropriate ways to enlighten members of the community of the difficulties faced by deprived of family care, and the importance of the availability of alternative families for this category, and urged people to participate in the program of alternative families, and to focus on the religious side to get them and convince them to do so.

- Adopting a program that can be called a "link between the foster care and the community" through which coordination with government institutions and non-governmental, and contains activities and events designed to connect and integrate foster care youth in the community early, and help them adapt and interact with society, so as to facilitate it shift when moving to live in the community after the end of his stay in the organization.

- Designing and implementing a psycho-educational program for foster families to help and teach them how they can deal with adolescents in this stage.

- Extend foster care to age 21 years to ensure meeting of mental health needs of foster care adolescents.

\section{References:}

1. Adly, R., (2012): Describing the Care and Treatment of Orphans In Egypt Though The Perspectives Of Residents, Caretakers And Government Social Workers Dissertation Presented to the Faculty of the USC Rossier School of Education University of Southern California. In Partial Fulfillment of the Requirements for the Degree Doctor of Education. ProQuest Information and Learning Company: 1-124.

2. Arnett J., (2000): Emerging adulthood: A theory of development from the late teens through the twenties. American Psychologist, 55(5): 469-80.

3. Brandford C., (2002): Foster Youth Transition to Independence Study, Office of Children's Administration Research. Washington: 33-6.

4. Britner, P., \& Kraimer L., (2005): Abused and neglected youth. The Handbook of Youth Mentoring. Thousand Oaks, CA: Sage Publications: 482-92.

5. Child Welfare League of America, (2004): 
Kinship care: A New Look at an Old Idea. Washington: 6-7.

6. Chipungu S., and Goodley T., (2004): Meeting the Challenges of Contemporary Foster Care; Journal Issue: Children, Families, and Foster Care; 14 (1).

7. Collins M., (2001): Transition to adulthood for vulnerable youth: A review of research and implications for policy. Social Service Review Journal; 75 (2): 271-91.

8. Connelly, C.D. (1998): Hopefulness, selfesteem, and perceived social support among pregnant and nonpregnant adolescents. Western Journal of nursing Research, 20(2), 195-209.

9. Courtney E., Dworsky A., Lee S., and Raap M, (2010): Midwest Evaluation of the Adult Functioning of Former Foster Youth: Outcomes at Age 23 and 24. Child Welfare: 1-107.

10. Courtney E., Piliavin I., Grogan-Kaylor A., \& Nesmith A. (2001): Foster youth in transitions to adulthood: A longitudinal view of youth leaving care. Child Welfare, 80(6): 685-717.

11. Debra E. and Kelly S., (2003): Measurement Error in the Reported Reasons for Entry into the Foster Care System. Child Abuse and Neglect; 4 (23):33-4.

12. Ethnasios A., (2012): Preview Describing The Care And Treatment of Orphans In Egypt Through The Perspectives Of Residents, Caretakers And Government Social Workers . Dissertation submitted to the Faculty of the Virginia Polytechnic Institute and State University in partial fulfillment of the requirements for the degree of Doctor of Philosophy in Sociology. ProQuest Information and Learning Company: 1-189.

13. Fairbrother N., (2004): Social Support, Partners for Mental Health and Addictions Information. Wellness Module 3. BC.

14. Fontes A., and Wanchic F., (2004): Be Loved Outcasts. The Cairo Times; 8 (4).

15. Gilborn L., Lou A., Jonathan B., Linda D., Kyle J., Mark K., Tricia S., and Leslie S., (2006): "Orphans and vulnerable youth in Bulawayo, Zimbabwe: An exploratory study of psychosocial well-being and psychosocial support," Horizons Final Report. Washington: 12.

16. Harter, S. (2006): Adolescence is a time of significant social, cognitive, physical, and emotional change. Learning and Individual Differences. Elsevier Sponsored Documents; 21(6): 681-9.
17. Hurley K., (2011): In Transition: A better future for youth leaving foster care. Child Welfare and Watch; 19\& 20.

18. Johnson D., (2010): The Relationship between Social Support and Psychological Problems among Students, International Journal of Business and Social Science 1 (3): 110-5.

19. Johnson S., (2009): Therapeutic Mentoring: Outpatient for Youth in Foster Care. A Disseration Submitted to the Faculty of the Graduate School in Candidacy Program in Social Work. Loyola University Chicago. ProQuest Information and Learning Company: 1-127.

20. Leslie K., Landseverk J., lofstrom R., Tschann M., Slymen J. and Garland F., (2000): Children in foster care: Factors influencing outpatient mental use. Child Abuse and Neglect; 24 (4): 465 - 76.

21. Lois E., (2007): Long-term care: Factors affecting implementation of a staff participation system designed to foster a culture of continuous change. A Disseration Presented in Partial Fulfillment of the Requirements for the degree Doctor of Philosophy. Capella University, ProQuest Information and Learning Company: 1128.

22. Lovibond P.F. and Lovibond S.H., (1995): The Structure of Negative Emotional States: Comparison of the Depression Anxiety Stress Scale (DASS) with the Beck Depression Anxiety Inventories. Behavioral Research and Therapy; 33: 335-43.

23. Norbeck, J.S., Lindsey, A.M., \&Carrieri, V.L. (1983): Further development of the Norbeck social support questionnaire: Normative data and validity testing. Nursing Research; 32: 4-9.

24. Nugent N. and Masuku Z.,(2007): Psychosocial Support for Orphans and Vulnerable Children. An Introduction for Outreach Workers. Bantwana Initiative for Orphans and Vulnerable Children: 1-9.

25. Oosterman M., Schuengel C., Slot W., Bullens R. and Doreleijers T., (2007): Disruptions in Foster Care: A review and Meta-Analysis: Children and Youth Services Review: 53-76.

26. Samuels, G.M. (2008): A Reason, a Season, or a Lifetime: Relational Permanence among Young Adults with Foster Care Backgrounds. Children and Youth Services Review; 30 (10): 198 - 210.

27. Scott E., (2008): Lived Mental Health Experiences of Adolescents of Color In Foster Care. A Disseration Submitted to the Case Western Reserve University, United States .Ohio. Ann Arbor. ProQuest Information and Learning Company: 1-220.

28. Slymen D., and Garland A., (2000): Children 
in foster care: Factors influencing outpatient mental health service use. Child Abuse and Neglect 25(4): 465-76.

29. Stukes S.C., and Bent G.T., (2009): Meeting the challenges of contemporary foster care. The Journal of Children 14 (1): 75-93.6.

30. Taylor, D., Lichstein, K., Durrence, H., Reidel B and Bush, A., (2005): Epidemiology of Insomnia, Depression, and Anxiety. Sleep Journal; 28 (11): 1457- 64.

31. Wertheimer R., (2002): Youth who "age out" of Foster Care: Troubled Lives, Troubling Prospects. Child Trends; Washington: 1-6.

32. Whelan, D. (2003). Using attachment theory when placing siblings in foster care. Child and Adolescent Social Work Journal, 20 (1): 21-36.

33. World Health Organization (WHO), (2012): Adolescent health.

34. Yvonne A . Unrau, John R. Seita \& Kristin S. Putney (2008): Former foster youth remember multiple placement moves: A journey of loss and hope. Children and Youth Services Review; (30): 1256- 66. 